\title{
Diversidade sexual e de gênero no sistema prisional: discriminação, preconceito e violência'
}

\section{Eder Aparecido de Carvalho²}

Alexandre da Silva de Paula ${ }^{3}$

Sergio Kodato ${ }^{4}$

Resumo: Este estudo aborda a realidade do sistema prisional brasileiro, mais especificamente o fenômeno das violências e agressões que atingem o segmento carcerário GBT (gays, bissexuais, travestis, transexuais e transgêneros), em unidades prisionais masculinas. Discute-se o quanto o cumprimento da pena implica em maior sofrimento para esse grupo, uma vez que, na dinâmica carcerária, a discriminação e o preconceito, associados ao gênero e à orientação sexual, constituem-se em justificativas para os atos de marginalização e exclusão. O objetivo deste artigo é dar visibilidade ao sofrimento institucional desses

1 Oportuno esclarecer que o texto é construído (somado às contribuições teóricas) com base em uma perspectiva vivencial, ancorada metodologicamente na observação participante, uma vez que um dos autores observou, durante quinze anos (como servidor da Administração Penitenciária de um Estado do Sudeste), os meandros do sistema carcerário, os agenciamentos coletivos e as práticas discursivas (em gírias institucionais) que impõem um lugar subalterno e marginal à população carcerária de GBTs.

2 Instituto Federal Catarinense (IFC) - Brusque - Brasil - carvalhoeder@hotmail.com

3 Instituto Federal de São Paulo (IFSP - Campus Votuporanga) e Centro Universitário de Votuporanga (UNIFEV) - Votuporanga - Brasil - aledpaula@outlook.com.

4 Faculdade de Filosofia, ciências e Letras - Universidade de São Paulo (USP - Campus Ribeirão Preto) Ribeirão Preto - Brasil - skodato@ffclrp.usp.br 
sujeitos e, consequentemente, subsidiar a construção de estratégias e dispositivos de prevenção e combate à violência e à crueldade institucional.

Palavras-chave: Sistema Prisional. Identidade de Gênero. Orientação Sexual. Público Carcerário.

\section{Sexual and gender diversity in the prison system: discrimination, preju- dice and violence}

Abstract: This research approaches the reality of the Brazilian prison system, more specifically, the phenomenon of the violence and aggression in the GBT (gays, bisexuals, transsexuals and transgender) prison segment, in masculine prison units. It also discusses how much the execution of a custodial sentences implicate in a higher suffering for this group, since, in the prison dynamics, the discrimination and prejudice, associated with the gender and sexual orientation, are a way to justify the marginalization and exclusion acts. The objective of this article is to give visibility to these individuals' institutional suffering and, consequently, subsidize the construction of strategies and mechanisms to prevent and combat the institutional violence and cruelty.

Keywords: Prison System. Gender Identity. Sexual Orientation. Prison Population.

\section{Introducç̃o}

Esta pesquisa procurou investigar a dinâmica conflituosa do sistema prisional brasileiro, mais especificamente a intensificação da violência institucional que atinge gays, bissexuais, travestis, transexuais e transgêneros $(\mathrm{GBT})^{5}$, em unidades carcerárias masculinas. Nesse sentido, buscou-se analisar o quanto a privação de liberdade, nessas condições, é danosa para a subjetividade e sobrevivência do segmento $\mathrm{GBT}^{6}$, uma vez que, nesse contexto, a discriminação, o estigma e o preconceito, associados ao gênero e à orientação sexual, fazem

5 Neste texto, todas as vezes em que houver menções aos transexuais e transgêneros, refere-se às mulheres transexuais e às mulheres transgêneros ou, simplesmente, mulher trans. Trata-se daquela que, mesmo tendo nascido em um corpo biologicamente masculino (designado, consequentemente, como pertencente ao gênero masculino), identifica-se como sendo do gênero feminino.

6 Neste texto, todas as vezes em que houver menções aos transexuais e transgêneros, refere-se às mulheres transexuais e às mulheres transgêneros ou, simplesmente, mulher trans. Trata-se daquela, mesmo tendo nascido em um corpo biologicamente masculino (designado, consequentemente, como pertencente ao gênero masculino), que se identifica como sendo do gênero feminino. 
parte do cotidiano das relações sociais7. Essa forma de organização prisional acaba por tornar mais cruel e perverso o modelo de exclusão e violência contra as minorias.

Diante dessa realidade, neste estudo, teve-se como objetivo descrever e analisar as relações de violência e violações de direito que atingem a comunidade de gays, bissexuais, travestis ${ }^{8}$, transexuais e transgêneros numa unidade prisional, localizada no interior de um Estado do Sudeste brasileiro. Metodologicamente, fundamenta-se na microssociologia de Erving Goffman, tendo em vista os processos de mortificação do "eu", implicados na tensão permanente e hostil entre heterossexuais e homossexuais'; os sistemas de ajustamento e resistência às regras e normas, ou os instituídos pela equipe dirigente ou os impostos pelos internos que ocupam posição de liderança e detêm o poder de mando; e, por fim, as gírias e expressões linguísticas institucionais que revelam códigos morais e éticos rigorosos, dificilmente violados, os quais implicam em vulnerabilidade e risco para a minoria em foco.

A identidade de gênero e a orientação sexual dos sujeitos envolvem conceitos complexos. Nas prisões, é notório os internos elaborarem códigos verbais e uma linguagem peculiar para se referirem às práticas sexuais. Trata-se de expressões, ou gírias, muito utilizadas no dia a dia, que interferem nas relações interpessoais, na compreensão de si e da própria sexualidade, no ambiente do cárcere. Diante disso, este artigo não almeja aprofundar-se teoricamente na terminologia que se refere à orientação sexual ou à identidade de gênero. A linguagem aqui adotada, ao abordar o público-alvo da pesquisa, traz à tona a experiência da cultura de um regime de reclusão, o qual se objetiva em práticas de assujeitamento, depreciação, humilhações e perversões violentas.

Trata-se de um estudo de análise de grupos e instituições embasado na perspectiva etnográfica, em que o pesquisador incursiona e observa diretamente a realidade dinâmica dos participantes, no campo de pesquisa. Os dados foram coletados por meio da observação de participante da rede de interações, do

7 Importante esclarecer, como já fez Zamboni (2017), que no contexto do sistema prisional não há separação entre identidade de gênero (o gay, a travesti, a transexual - por exemplo) e orientação sexual (heterossexual, bissexual, homossexual e assexuado). Ser travesti ("bicha", "mona" etc.) também é ser homossexual (gay, "veado" etc.).

8 Os companheiros das travestis (chamado de "marido") não são considerados (pela população carcerária) heterossexuais (homens cisgêneros). Também são tratados como se fossem as chamadas "bibas", "veados, etc.

9 No decorrer deste texto, procurando respeitar a formulação local (seio prisional), heterossexual corresponde ao chamado "sujeito homem" - aquele que possui genital masculino e mantém relação com mulheres cisgêneras. Enquanto o homossexual seria ser o gay, "veado", "biba" (ZAMBONI, 2017). 
contexto e do cotidiano institucional e foram registrados no diário de campo da pesquisa.

Buscou-se a análise sistemática das relações e interações entre os internos heterossexuais (aqui entendidos como o chamado "sujeito homem") e a comunidade GBT, no cotidiano da unidade prisional, em momentos e situações estratégicas, como: a distribuição e negociação não oficial de tarefas, a dinâmica das refeições e descanso, a comunicação entre os internos, os códigos de silêncio, os processos de admissão e, ainda, a aplicação de sanções ou penalidades pelos próprios internos.

Enquanto problema da pesquisa, perguntou-se: será que o segmento carcerário de GBT, no cotidiano da prisão, estaria sendo submetido e capturado pelas relações hierárquicas e regras relacionadas à heteronormatividade ${ }^{10}$ ? Ou seja, será que as manifestações sexuais e de gênero, distintas da heterossexual, estariam sendo marginalizadas, estigmatizadas e perseguidas nos espaços de poder, convivência comum e possibilidade de cidadania?

Os registros do diário de campo, analisados em sua diversidade temática, indicaram aspectos relevantes da dinâmica institucional e foram sistematizados nos seguintes analisadores: a) o público GBT é submetido e obrigado a fazer a faxina e limpeza das celas e lavar as roupas e pratos dos outros presos. Na prática, eles acabam por desempenhar o papel da figura feminina dentro do cárcere e se não cumprirem as tarefas previstas estão suscetíveis à agressão e a outras punições; b) gays, bissexuais, travestis, transexuais e transgêneros estão proibidos de exercer algumas atividades mais "dignas", como trabalhar na cozinha ou na "manutenção"; c) os integrantes da população GBT nunca se expressam ou fazem uso da palavra nos momentos de debate público, no pátio da unidade, pois não têm acesso à "palavra" para manifestar suas opiniões; d) a maioria dos presos GBTs não recebe visitas dos próprios familiares.

Nesse sentido, buscou-se analisar e compreender criticamente os meandros da violência e discriminação contra as minorias homossexuais e demais sujeitos (travestis ou transgêneros), no contexto prisional. Como essas minorias buscam garantir sua sobrevivência e relações de adesão ou não captura pelas facções do crime organizado? A violência e a discriminação, no período de cumprimento da pena, de que forma afetam e efetivam a ressocialização dos

10 O público de GBT (que no entendimento local seriam aqueles que não se enquadram nos "padrões" de masculinidade: "monas", "bichas", "bibas", travestis etc.) estaria submetido às regras do "sujeito homem" - aqueles que, por sua vez, enquadram-se nos "padrões" de masculinidade (Zamboni, 2017). 
apenados, especialmente das minorias? Como se dá a promoção de ações de direitos humanos, cidadania e ética nas relações prisionais?

\section{GBTs em cumprimento de pena}

As prisões surgiram no Século XIX, tendo um papel, teórico, de substituir a punição por castigo corporal cruel e violento, como o suplício, as diversas formas de tortura, o enforcamento, a fervura em óleo quente ou o apedrejamento. O homem moderno se pautou na doutrina jurídica para repreender e penalizar os criminosos. Desta forma, esperava-se que no Século XXI o cidadão que infringisse a lei (ou pacto social) fosse devidamente julgado, em face de um código condizente - preceitos fundamentais como a ordem pública e o bem comum.

O protesto contra os suplícios é encontrado em toda a parte na segunda metade do século XVIII: entre filósofos e teóricos do direito; entre juristas, magistrados, parlamentares e entre os legisladores das assembleias [...]. É preciso punir de outro modo, eliminar essa confrontação física entre o soberano e o condenado, esse conflito frontal entre a vingança do príncipe e a cólera contida do povo, por intermédio do carrasco (Foucault, 1989: 71).

De fato, a modernidade foi um período em que foram depositadas muitas esperanças no sistema jurídico. No decorrer do Século XIX, novas doutrinas jurídicas foram elaboradas na Europa, tendo como meta atingir o crescimento de crimes praticados contra o patrimônio pessoal, em detrimento do declínio de homicídios e mortes sangrentas. Ou seja, a partir da Revolução Industrial, houve mais ataques aos bens privados do que crimes contra a integridade física do outro. As instituições de reclusão (presídios) surgem nesse contexto histórico, no qual novas táticas do Estado Moderno eram colocadas em prática para atingir um alvo específico (o delinquente urbano), que era largamente difuso no corpo social. Surgiram novas técnicas de punição, além do suplício no corpo, "novos princípios para regulamentar, afinar e universalizar a arte de castigar" (Foucault, 1989: 87).

A humanidade poderia confiar, agora, em juízes, promotores e magistrados responsáveis por defender a sociedade dos indivíduos de má índole, dos perversos, dos psicopatas, dos estupradores e homicidas. Essa população de infratores e transgressores da lei passaria por um longo período de reclusão para tratamento moral e disciplinar, de tal forma que antigos hábitos e condutas inadequadas fossem corrigidos. Mas, é notória a atual descrença popular na capacidade de correção, arrependimento ou aquisição de valores pelos detentos. 
Sendo assim, é comum ouvirmos que o massacre do Carandiru eliminou uma parcela de criminosos irrecuperáveis ${ }^{11}$, sendo uma ação exemplar de combate aos criminosos. Esse tipo de afirmação contém, notadamente, a cólera e a vingança ao outro, como princípio capaz de imputar a ordem e reverter a violência urbana.

É como se o bandido, julgado e cumprindo pena em regime fechado, fosse muito bem tratado nos presídios: alimenta-se, dorme, não produz e ainda é mantido com dinheiro honesto de impostos. Soma-se a isso que prevalece o discurso de periculosidade incontrolável, o interno é percebido como sujeito ingovernável e intratável e, por essa razão, perigoso, a sua conduta escaparia da gestão institucional (Vicentin, 2010).

Por outro lado, a história nos mostra que a vingança, enquanto princípio da ordem social, não implica em solução para o mal que atinge a todos, mas, sim, na multiplicação indefinida de mais mortes e mais violência. As instituições de reclusão foram planejadas para que os criminosos tivessem uma resposta do Estado, pautada não apenas no senso de vingança ou "olho por olho e dente por dente". Entretanto, não é de hoje que o sistema prisional brasileiro apresenta um funcionamento que beira o caos. Neste contexto, destaca-se que:

[...] além da deformação pessoal que decorre de a pessoa perder seu conjunto de identidade, existe a desfiguração pessoal que decorre de mutilações diretas e permanentes do corpo - por exemplo, marcas ou perda de membros. Embora essa mortificação do eu, através do corpo, seja encontrada em poucas instituições totais, a perda de um sentido de segurança pessoal é comum, e constitui fundamento para angústias quanto ao desfiguramento (GOFFMAN, 1979: 29).

Se a proposta é de reclusão (isolamento social) com reeducação, para que, no futuro, esses sujeitos possam retornar para o convívio social, problematiza-se a situação do detento que se depara com vários impedimentos, além de situações penosas com punição severa, as quais podem ser estabelecidas e acordadas entres grupos (facções) distintos ou rivais. "Nesta posição de expulso, o sujeito já perdeu sua visibilidade na vida pública, não tem voz, entrou no universo da

11 As rebeliões, no complexo penitenciário Anísio Jobim (que resultou na morte de 56 detentos em Manaus, Amazonas), na Penitenciária Agrícola de Monte Cristo (que resultou na morte de 33 presos em Boa Vista, Roraima) e na Penitenciária de Alcaçuz (que ocasionou a morte de 26 presidiários no Rio Grande do Norte), motivadas, em janeiro de 2017, pela disputa da hegemonia de facções rivais, nos presídios do Norte e Nordeste, também trouxeram (infelizmente) à tona este sentimento de que se tratava de uma parcela de criminosos irrecuperáveis - referindo-se aos óbitos. 
indiferença. É um sujeito absolutamente determinado: sem possibilidades, sem nome, sem potência" (Vicentin, 2010: 50).

Segundo Pinheiro e Gama (2016), quando se trata de abrigar os detentos do sistema prisional, o Brasil possui somente $50 \%$ das vagas necessárias. Percebe-se (de início) um déficit imenso. Seria preciso dobrar a capacidade das prisões para minimizar os tantos problemas do sistema carcerário. Leituras mais otimistas - dentre elas, Almeida e Chies (2016) e Eustaquio Junior et al. (2015) - trazem que, para atender à demanda por vagas no sistema carcerário, seria necessário aumentar em 50\% o número de espaços existentes - nível de ocupação por volta dos $150 \%$ (considerando apenas os presos inseridos no sistema carcerário e desconsiderando os presos em regime aberto e os que estão em liberdade condicional).

Fato é que o Brasil apresenta aproximadamente 350 presos, somados os presos provisórios (aguardando julgamento) e os presos já sentenciados, para cada 100 mil habitantes. Esses números vão ao encontro daqueles expressos nos relatórios do Ministério da Justiça (Departamento Penitenciário Nacional: Informações Penitenciárias - INFOPEN): 726.712 mil presos (junho de 2016), 97\% acima daquilo que comportam as prisões brasileiras. Deste total, 40,2\% aguardam julgamento. Outro dado assustador é que, de 2004 até 2016, a população carcerária cresceu $100 \%$ - aproximadamente $8,5 \%$ ao ano. Ou seja, maior que o ritmo das vagas disponibilizadas (mesmo que quase triplicadas na última década).

Outro problema é que a superlotação favoreceu o surgimento (consolidação) de grupos organizados - facções criminosas. Esse fato retrata o descaso e desmonte da concepção de estado democrático de direito e, consequentemente, uma dinâmica institucional imposta pela "lei do mais forte". O que se tem são as violações de direitos humanos, vistas as condições inadequadas de habitabilidade e salubridade. Neste contexto, na realidade do sistema prisional brasileiro citada, percebe-se a intensificação de violações e de privações quando se remete ao público carcerário de $\mathrm{GBTs}^{12}$. A carga física e psíquica da experiência prisional é mais acentuada para os gays, bissexuais, travestis e transexuais ${ }^{13}$, uma vez

12 Este texto retrata a realidade das unidades prisionais masculinas - consequentemente, diz respeito às condições a que estão submetidos os presos gays, bissexuais, travestis, transexuais e transgêneros (GBTs). Embora a redação não tenha aprofundado sobre o cotidiano das unidades prisionais femininas, e que possuem lésbicas (além de bissexuais, transexuais e transgêneros), certamente muito do discutido se enquadra na realidade destas.

13 Seguindo o disposto na Resolução Conjunta no 1, de 15 de abril de 2014 (Resolução Federal): 1) Gays: denominação específica para homens que se relacionam afetiva e sexualmente com outros homens; 2) Bissexuais: pessoas que se relacionam afetiva e sexualmente com ambos os sexos; 3) Travestis: pessoas que pertencem ao sexo masculino na dimensão fisiológica, mas que socialmente se apresentam 
que, no âmbito carcerário, a discriminação e o preconceito, associados ao gênero e à orientação sexual, são intensificados - os GBTs são alvo fácil de agressões (físicas e psicológicas) e de todas as formas de humilhação e estigmatização, dentro do sistema prisional.

As condições de vida desse segmento, em situação de cárcere, são ainda mais degradantes quando comparadas com os "sujeitos homens" (aqueles que gostam só de mulher), na mesma realidade. A prisão consegue tornar mais intenso e perverso o modelo de exclusão e violência. Diante do exposto, no que se refere aos GBTs no âmbito prisional, existe uma preocupação maior em termos da segurança e integridade desse público, visto que as relações de poder são evidenciadas por hierarquias e obediências - manutenção do poder heterossexual (domínio do "sujeito homem"). As assimetrias estabelecidas na sociedade, na qual o heterossexual é situado dentro da norma social e o homossexual como desvio dos padrões, têm grande influência no ambiente interno dos presídios.

Quando os GBTs são inseridos no ambiente carcerário, exclusivamente masculino, supõe-se que deveria ocorrer, por parte do poder público, grande preocupação com o bem-estar físico, psíquico e sexual desses indivíduos, haja vista a existência de uma cultura homofóbica e transfóbica que perpassa a interação entre homossexuais e heterossexuais. Nessa perspectiva, coloca-se em xeque a constituição desse segmento como sujeitos de direitos e deveres com a sociedade (Eustaquio Junior et al., 2015). Está posto o desafio para o Estado, considerando as condições precárias do público GBT em situação de cárcere "domesticado", segundo as regras do ambiente prisional.

É possível iniciar o retrato do cotidiano em questão, ilustrando os processos de admissão (inclusão no sistema carcerário). É comum que a obediência do preso (e aqui não se refere apenas aos GBTs) seja testada pelos agentes públicos, nos rituais de inclusão - desde o desembarque do "bonde" (viatura oficial que transporta os presos de uma unidade prisional para outra): "mão para trás", "cabeça baixa", "de frente para parede", "pede licença quando passar pela porta”. Ou seja, os rituais envolvem provocações e pequenas humilhações ao presidiário, os quais terão a função de cerceamento e mortificação do eu, operando mudanças em sua subjetividade e atitudes aprendidas, ao longo da trajetória

no gênero feminino, sem rejeitar o sexo biológico; e 4) Transexuais: pessoas que são psicologicamente de um sexo e anatomicamente de outro, rejeitando o próprio órgão sexual biológico. A Resolução da Secretaria Estadual da Administração Penitenciária do Rio de Janeiro (SEAP 558), de 29 de maio de 2015, também traz no seu parágrafo $3^{\circ}-$ art. $1^{\circ}$ : Entende-se por pessoa travesti e mulher transexual a pessoa do sexo biológico masculino e identidade de gênero feminina e homem transexual a pessoa do sexo biológico feminino e identidade de gênero masculina. 
existencial conflituosa. $\mathrm{O}$ objetivo é desconstruir a identidade social deste detento, punindo de forma humilhante a transgressão da lei e a prática de crimes $^{14}$.

Portanto, o internado descobre que perdeu alguns dos papéis em virtude da barreira que o separa do mundo externo. Geraimente, o processo de admissão também leva a outros processos de perda e mortificação. Muito frequentemente verificamos que a equipe dirigente emprega o que denominamos processos de admissão: obter uma história de vida, tirar fotografia, pesar, tirar impressões digitais, atribuir números, procurar e enumerar bens pessoais para que sejam guardados, despir, dar banho, desinfetar, cortar os cabelos, distribuir roupas da instituição, dar instruções [...] (Goffmann, 1974: 25).

Toda a ação do presidiário novato passa a ser controlada, planejada e disposta num esquema que visa à disciplina, à ordem e à obediência a um novo código, com regras e barreiras difíceis de serem quebradas. Cabe, ainda, pensar em como se dá o funcionamento e estruturação do poder nos presídios, onde a ausência do poder institucional abre brechas para a organização interna dos próprios presidiários. Ou seja, essas características da instituição prisional, na qual o poder paralelo dos internos (via de regra ligados a organizações criminosas) se sobrepõe aos preceitos dos agentes públicos, para não dizer do próprio Estado, implicam em um estado de tensão e conflitos permanentes.

É prudente destacar que, da mesma forma que na hierarquia formal ocorrem os testes de obediência e as "boas-vindas" aos novatos, a relação entre o grupo de estabelecidos (presos veteranos) e o grupo de submissos (novatos) também é marcada por hierarquias que situam "o outro" (novato) como "inferior, sujo e contagioso".

Importante esclarecer que os itens numerados a seguir (1 a 8) emergiram e foram categorizados, com base na análise temática dos registros do diário de campo, e representam como os GBTs lidam no cotidiano das prisões, com as regras de obediências e hierarquias, bem como com a violência e crueldade institucional:

14 Oportuno esclarecer que o texto em tela não pretende tratar (de maneira direta) sobre as atribuições e dificuldades vivenciadas pelos agentes públicos (especialmente dos agentes de segurança penitenciária), haja vista que também são dominados pela cultura do medo - bastando observar a superpopulação carcerária, contingente insuficiente de agentes, más condições de trabalho e segurança. 
1) Submetidos (obrigados) a fazer faxina (limpeza) na cela e a lavar a roupa e pratos dos outros presos ${ }^{15}$. Na prática, são os primeiros a acordar e os últimos a dormir - são a figura feminina dentro do cárcere e se não cumprirem as tarefas prescritas estão sujeitos à agressã $0^{16}$. São frequentes as situações em que não são aceitos na cela só pelo fato de serem gays, travestis, transexuais ou transgêneros. Quando isso acontece, são obrigados a ir para o "seguro", ala isolada onde ficam os presos que não têm convivência com a população carcerária - dentre eles, os estupradores, membros de facções rivais, "talaricos" (sujeitos que quando em liberdade tiveram relações amorosas com mulheres de indivíduos presos) etc.

2) Os presos GBTs estão impossibilitados de exercer algumas atividades específicas dentro do presídio. Devido ao preconceito, estão impedidos de trabalhar na cozinha, na "faxina" ${ }^{17}$ e na "manutenção" - por

15 Perfeitamente possível encontrar discursos tentando desconstruir a afirmação de que existe a obrigação de realizar a faxina (afazeres "domésticos") por parte daqueles que não se enquadram nos "padrões" de masculinidade (as "monas", "bichas", "bibas", travestis etc.). Por outro lado, daria para responder que há prisões e prisões - no entanto, a paciência com o público GBT é sempre reduzida, e qualquer "deslize" os coloca como "esquema" da cela, quando não, são obrigados a pedir "seguro" (pavilhão reservado para os detentos que não têm convivência com os demais presos).

16 Oportuno esclarecer que os trabalhos impostos (à força) não são (e nunca foram) direcionados exclusivamente ao público GBT. Detentos que de alguma maneira contraem pequenas dívidas dentro do cárcere (especialmente com drogas) também são obrigados - contra as suas vontades - a assumir algumas responsabilidades. Estas vão desde limpeza da cela até assumirem responsabilidades por delitos de que não são autores. Exemplo: quando em uma revista de cela, efetivada pelos servidores da Administração Penitenciária (agentes de segurança), é descoberto um aparelho celular ou mesmo drogas (maconha ou cocaína), é sabido que algum indivíduo da cela sempre aparece como proprietário do ilícito. É claro que nunca se tem a garantia de que quem assumiu a propriedade é o dono do "objeto" de fato. Ou seja, muitas das vezes quem assume é o "lagarto" (preso com menos poder e muitas vezes aquele que tem que pagar alguma dívida - também chamada de "comédia"). Oportuno trazer que a verdade acaba muitas vezes sendo conhecida no decorrer dos interrogatórios (apuração dos fatos) no interior das unidades prisionais ou mesmo nas delegacias, durante oitivas subsequentes. É claro que o objetivo dos agentes públicos é sempre encontrar o real autor da infração. No entanto, certamente (por não terem "bola de cristal"), isso nem sempre é possível.

17 Neste sentido "faxina" se refere a um grupo de presos que servem as refeições e limpam o pátio do pavilhão. Também "zelam" pela "disciplina" do pavilhão - respeito à "ética" do mundo do crime. Os "faxinas" também são espécie de "palavras" do pavilhão (também chamado de "raio"). Quando um detento tem de resolver uma situação com outro encarcerado precisa do "aval" dos "faxinas". Muitas vezes, compondo a "faxina" está o "palavra" do pavilhão (o bandido mais ouvido pelos demais presos). No entanto, quando o "palavra" não faz parte da "faxina" e tem decisão importante para ser tomada, aquele sempre é consultado por esta. Os "faxinas" são escolhidos pela direção da Unidade Prisional. Quando é necessário trocar preso na "faxina" (geralmente motivado por transferência, liberdade ou mesmo indisciplina), é pedida uma relação de alguns nomes para os "faxinas" remanescentes, para que a diretoria da prisão efetive a escolha. Certamente, nesta relação não constam nomes de detentos GBTs. Nem para trabalhar na "faxina", nem na "manutenção" e muito menos na cozinha. 
exemplo. Como trabalhar na cozinha (segundo a moral do "crime") se, supostamente, colocam a mão ou a boca no órgão genital de outro detento? Isso é questão de higiene e trabalhar na cozinha, segundo lei imposta pela população carcerária, nem pensar! Como trabalhar na manutenção (expressão usada para detentos que realizam consertos e reparos)? Isso é coisa para homem e não para "bibas". Como trabalhar na "faxina"? A "faxina" é para bandidos (aqueles que têm que "manter" a "disciplina") e não para "bichas". Sem falar que é a "faxina" que serve o almoço para os outros detentos, e uma "mona" colocando as mãos nas marmitas (cumbucas de plásticos) também (indo ao encontro do pensamento que impede trabalhar na cozinha) não seria higiênico.

3) Em uma cela na Unidade Prisional (qualquer que seja), os presos em muitos aspectos se comportam como se fossem entes de uma mesma família. Por exemplo: em uma residência todos os integrantes da família fazem uso dos mesmos talheres, pratos, copos etc. Uma cela funciona do mesmo jeito: o prato que é lavado fica em um espaço (espécie de prateleira) que é de uso coletivo. Também é muito comum os detentos, em razão da superlotação, dormirem na mesma cama em posição chamada de "valete" (posição invertida: pés de um lado, cabeça de outro). No entanto, os presos "ditos" heterossexuais não gostam (não querem) de ficar sentados ou dormir ao lado de detentos "ditos" homossexuais. E tomar água no mesmo copo, comer no mesmo prato ou fazer uso do mesmo talher? Nesses aspectos, a "família cai por terra", e a homofobia e transfobia prevalecem. O descaso é tão grande que as marmitas (cumbucas plásticas em que é servida a alimentação e que são despachadas da cozinha para os pavilhões) que são servidas aos gays, bissexuais, travestis, transexuais e transgêneros são queimadas com "bituca" de cigarro (também possuem tampas em cor diferente). Isso para impedir que marmitas que são servidas aos GBTs, em um dia, sejam servidas aos "sujeitos homens" em outro. Como pode um "bandido" se alimentar no mesmo "bandeco" (marmita) de um indivíduo "afeminado" que pratica sexo oral? 0 "crime" não aceita.

4) Quando são incluídas na Unidade Prisional, as travestis e transexuais têm seus cabelos raspados ${ }^{18}$. Também são obrigadas (por questões que

18 Essa prática de raspar o cabelo prevaleceu por muitos anos (e até recentemente) no sistema carcerário. No entanto, a legislação (âmbito federal e estaduais) tem garantido às travestis e transexuais o direito de manutenção do cabelo na altura dos ombros. E mais que a garantia meramente legal tem existido, salvo exceções de unidades prisionais que desrespeitam as regras estabelecidas com relação ao comprimento 
envolvem segurança) a vestirem uniformes cedidos pela Administração Penitenciária (uniformes masculinos, uma vez que estamos tratando de unidades prisionais para pessoas do sexo masculino). Ou seja, se o uso deste uniforme não é exigido no convívio do pavilhão, é obrigatório nos momentos de deslocamento: atendimento judiciário, atendimento médico, atendimento com equipe técnica (assistentes sociais ou psicólogos), atendimento com advogado etc. A mesma conduta também é exigida quando é necessário deslocamento externo: audiências com juízes nos Tribunais de Justiça, por exemplo.

5) A discriminação em relação ao público GBT, no sistema carcerário, nada mais é que sintoma da sociedade preconceituosa, um traço da cultura homofóbica e transfóbica que se encontra do lado externo da prisão. Tanto que a maioria dos presos gays, bissexuais, travestis, transexuais e transgêneros não recebe visitas dos familiares. Ou seja, as famílias de origem não aceitavam a identidade de gênero do ente muito antes de este ingressar no sistema carcerário e, após cometer ato criminoso, acaba por ser ainda mais isolado.

6) É comum a população carcerária se reunir no pátio ou quadra esportiva para acertar questões do cotidiano prisional. Os assuntos (recados) podem ser os mais variados (respeitar os funcionários, respeitar as visitas, economia de água, enfeites para serem colocados no pátio no Dia das Mães etc.). Nesses debates, um ou outro detento acaba se impondo - às vezes, por se expressar melhor, mas quase sempre quem fala é alguém da "faxina" ou algum preso "considerado" - tido como "bandido" e, via de regra, ligado a alguma facção criminosa. Os gays, bissexuais, travestis, transexuais e transgêneros privados de liberdade nunca se expressam (nunca falam), pois não têm direito ao uso da "palavra". E se houver algum GBT corajoso muito provavelmente será cerceado. Só para comprovar os argumentos (indo na mesma direção), os chamados "monas", "bichas", "bibas", "veados" não são aceitos em facções criminosas. Inclusive, a paciência com esse público é sempre escassa - qualquer

do cabelo, uma execução da lei, e as travestis e transexuais de cabelo longo têm permanecido com cabelo comprido, quando é de sua vontade. De acordo com as resoluções adotadas (Federal e Estaduais), os cabelos longos das pessoas travestis e das transexuais deverão ser mantidos (se assim as pessoas desejarem) na inclusão, nas transferências e na permanência no sistema carcerário. 
descuido é motivo para ser convidado a deixar o pavilhão e ir para o "seguro"19.

7) No sistema carcerário, existem palavras que são proibidas. Os servidores ou mesmo presidiários não podem, em hipótese alguma, dirigir-se a um grupo de presos dizendo "moçada". Certamente haverá ofendidos, uma vez que a palavra correta é "rapaziada". Isso tudo porque "moçada" subentende grupo de moças. Também não se pode dirigir a um preso "macho", "bandido", a palavra "diferente". Por exemplo: oficial de justiça (poderia ser qualquer outro profissional) se apresenta na Unidade Prisional para atender a um detento. Imediatamente este preso será informado no pavilhão, pelos agentes públicos, sobre o atendimento. Costumeiramente, esse preso veste uma camisa e calça (uniforme cedido pela Instituição Prisional) e, quando está pronto (muitas vezes toma até banho), é guiado para um local próprio para o atendimento - espaço chamado de parlatório. Vamos dizer, hipoteticamente, que esse preso se apresente de short e sem camisa para o atendimento. Neste caso, será pedido para colocar uma calça e uma camisa (uniforme). Imaginamos que o preso se negue a colocar a calça e o servidor (funcionário do pavilhão) pergunte para o detento se ele é "diferente" (fazendo alusão a que todos os encarcerados colocam o uniforme quando têm determinado atendimento). Dito isso, estará feita a confusão, pois este presidiário, entre outras palavras, dirá: "está me chamando de diferente?", "senhor está de brincadeira", "aqui é o crime", "aqui é vagabundo". Isso certamente aconteceria porque "diferente" na linguagem do mundo prisional são as "bibas" - "meninas". Enfim, o preconceito não

19 Oportuno esclarecer que os presos considerados "comédias" e os ligados à igreja quase nunca falam salvo se estiverem inseridos no contexto do "debate". São detentos - segundo a lei do "crime" - que também não têm "palavra". Os presos chamados de "evangélicos" só tomam a frente (se é que dá para dizer isso), quando se trata de alguma oração que é feita no pátio. Nesse momento, eles cantam e chamam para uma reza. Do resto, não "apitam" e não pronunciam - silêncio é a regra. Isso se justifica porque geralmente o preso se torna "evangélico" depois que está preso e, na maioria das vezes (há exceções), tem medo dos outros presos, por isso diz que é "evangélico". Isso acontece porque os presos "evangélicos" têm a sua própria cela e acabam não dividindo espaço com os chamados "criminosos". As regras para os detentos tidos como "evangélicos" também são bastante rígidas. Segundo as regras de algumas "igrejas" e mesmo as impostas pela população carcerária (há exceções), não podem ficar de bermuda nem na cela - por exemplo, mesmo se uma cela for para 6 presos e tiver 18. Mesmo que tiver a 50 graus Celsius. Ou seja, a vida dos chamados "evangélicos" também é complexa. A diferença é que o detento tem a opção de ser ou não "evangélico". Inclusive, há muitos presos "evangélicos" que depois de ter passado o medo inicial da prisão (dos outros presos) pedem para ir para cela dos detentos comuns. Os gays, bissexuais, travestis, transexuais e transgêneros (nos casos em que há cela separada para as pessoas GBTs) não têm esta opção. Na "cadeia" funciona como na "rua", e o preconceito prevalece: há ex-evangélico, mas não ex-travesti. 
aceita palavras que são costumeiramente usadas aqui do lado de fora dos muros das "cadeias".

8) Mensalmente, quinzenalmente, semanalmente ou diariamente (dependendo da necessidade), ocorrem revistas nas celas dos detentos. Essas vistorias, também chamadas de "blitz", são feitas pelos agentes públicos (agentes de segurança penitenciária). A revista pode acontecer em uma cela, em todas as celas do pavilhão ou na "cadeia" inteira - dependendo da demanda. Essas inspeções acontecem quando há suspeita de ilícito: armas, drogas, celulares, túneis etc. ${ }^{20}$ Importante ressaltar que em muitas dessas revistas já se sabe o que tem na cela de ilícito e, consequentemente, o que tem que se procurar. Por exemplo: se existe uma denúncia de que há celular em determinada cela, os agentes públicos promovem uma varredura na busca por celulares. Inclusive, é muito comum encontrar celulares e carregadores introduzidos no ânus de presos GBTs. Como se trata de uma "missão" desonrosa para os "bandidos", esse serviço sujo fica sob responsabilidade (salvo exceções) das "bichas" da cela. Ou seja, são muitas vezes obrigadas a se submeterem à tamanha humilhação e muito mais que violência física se tem uma expoente violência psicológica.

20 Não é intuito deste trabalho discutir como entram estes objetos no sistema carcerário. No entanto, a fim de não deixar margem para falsas interpretações, o ensaio vai trabalhar alguns esclarecimentos - mesmo que minimamente. É possível dizer que ilícitos dentro das prisões entram, quase que em sua totalidade (salvo exceções das exceções), de duas formas: funcionários corruptos ou visitas dos próprios presos. Importante trazer que tanto as visitas quanto os próprios servidores (quando iniciam a jornada de trabalho) são submetidos a revistas minuciosas. Passam, inclusive (visitas e servidores), por um detector de metais. É claro que isso não corresponde à realidade de todas as prisões, mas essa vistoria é feita em boa parte das unidades prisionais. E, mesmo assim, não se consegue evitar totalmente a presença de objetos ilícitos dentro dessas unidades prisionais. Ou seja, alguns "criminosos" que não estão presos (servidores e visitas mal-intencionadas) conseguem burlar a segurança. Oportuno deixar claro, e isso é de suma importância, que a maioria dos servidores (observado a quase inexistência de sindicâncias ou processos judiciais que envolvem conduta profissional desses) é comprometida com o exercício da profissão. É possível afirmar que são, de maneira geral, trabalhadores (essenciais ao aparato público) que deixam os seus familiares para exercer as suas atividades da melhor maneira possível. No entanto, se entre todos os servidores de uma unidade prisional (por exemplo) tiver um "agente público" que se deixa corromper, certamente, quando for pego praticando ato ilícito, provocará danos à imagem de todos os agentes públicos de todas as unidades prisionais. Também é possível tratar as visitas dos detentos da mesma maneira. A grande maioria são pessoas que têm a "simples" missão de visitar o seu ente querido. Propagam a boa e exclusiva intenção de levar uma palavra de conforto. São mães, pais, esposas, filhos, netos e avós que abrem mão de fins de semana para ir dar apoio ao ente querido que está recluso. Isso, inclusive, é fundamental para ressocialização do encarcerado. No entanto, se uma visita, no meio de tantas, é pega tentando entrar com produtos ilícitos no interior de uma prisão, certamente arranhará a imagem de todas as visitas. Enfim, sem mais delongas, necessário compreender que tanto servidores quanto visitas que praticam a corrupção no interior das prisões representam uma minoria e não a realidade. 
Tratados como "doentes e anormais", durante muito tempo os homossexuais vêm irrompendo cada vez mais luta pelos seus direitos e exigindo que estes sejam cumpridos. Nesse sentido, mesmo diante da discriminação e da repressão, os homossexuais têm buscado ampliar os seus direitos, no âmbito prisional. A legislação (fruto da luta dos movimentos sociais LGBTs) já apresenta princípios no sentido de preservar o direito à orientação sexual e à identidade de gênero consequentemente, garante-se o uso do prenome social (desde que requisitado pela pessoa privada de liberdade), uso de peças íntimas de acordo com a escolha do interno ${ }^{21}$ e a manutenção do cabelo na altura dos ombros. A legislação (Resolução SAP-SP no 11, de 30 de janeiro de 2014 - art. $\left.2^{\circ}\right)^{22}$ também traz:

As unidades prisionais podem implantar, após análise de viabilidade, cela ou ala específica para população de travestis e transexuais de modo a garantir sua dignidade, individualidade e adequado alojamento.

Parágrafo único: Para isso deve-se analisar o interesse da população assistida evitando assim segregação social ou quaisquer formas de discriminação negativa em razão da identidade de gênero ou orientação sexual.

O disposto na legislação citada visa a assegurar a integridade física e psicológica da população carcerária de travestis e transexuais (incluam-se os gays e transgêneros). No entanto, essa medida traz inquietações, uma vez que na prática não cessa o preconceito - exclui ao invés de incluir, haja vista que retira os detentos GBT do convívio com os demais presos heterossexuais - aqueles que, no âmbito prisional, são vistos e entendidos como "sujeitos homens". Talvez, a implantação de celas específicas para travestis e transexuais no seio do pavilhão de presos heterossexuais, após análise da viabilidade, colabore no que diz respeito à integridade do público GBT e minimize a segregação, uma vez que, no dia a dia (banho de sol, por exemplo), continua-se a assegurar o contato e a convivência dos heterossexuais com os homossexuais.

21 Com relação ao uso de peças femininas, como saias, shortinhos, blusinhas, dentre outras (referindo-se a unidades prisionais masculinas), tem se respeitado (na prática) este direito na intimidade e cotidiano do pavilhão (interior das celas e durante o banho de sol). No entanto, quando os atendimentos exigem a saída do pavilhão (advogado, médico, oficial de justiça etc.), as travestis, transexuais e transgêneros são obrigadas (por questões que envolvem segurança) a vestir uniformes masculinos cedidos pela Administração Penitenciária.

22 Neste caso, utilizamos um recorte da legislação em vigor no Estado de São Paulo (Resolução SAP n ${ }^{\circ}$ 11, de 30 de janeiro de 2014 - art. $2^{\circ}$ ). Importante trazer - no entanto - que com relação ao uso de prenome social, viabilidade de alas específicas para o público GBT, direito de manutenção dos cabelos longos e uso de peças íntimas, a legislação de outros Estados (e mesmo no âmbito Federal) também tem caminhado no mesmo sentido. 
Essa ação, diferentemente de pavilhões específicos para o público GBT (que tem sido adotado em alguns presídios pelo país), pode interferir na exclusão e, também, certificar maior segurança no período que estão no interior da cela período de descanso. Funcionaria como na dinâmica da sociedade. Ou seja, em um momento o indivíduo está seguro no interior da residência (com familiares) e no outro está no convívio da comunidade (seja no trabalho, escola, comércio etc.) - nestes contatos não se nota um apartheid entre homossexuais e heterossexuais. A prisão trata-se, ou ao menos deveria se tratar, de ambiente de ressocialização e deveria funcionar nos mesmos moldes da sociedade - na qual não se separa, ao menos fisicamente, os heterossexuais dos homossexuais.

O que se tem de concreto é que a discriminação e o preconceito contra os gays, bissexuais, travestis, transexuais e transgêneros são intensificados no sistema prisional. É também inegável a discriminação fora dos muros do cárcere, mas, no interior das unidades prisionais, essa prática social é acentuada. Inclusive, é possível afirmar que o maior desafio dos GBTs privados de liberdade (comparando aos GBTs livres) é conviver com seu agressor todos os dias e no mesmo espaço - pequena cela com número de detentos que quase sempre é o dobro (ou mais) da capacidade.

Esse convívio com o agressor poderia ser minimizado, compondo celas com apenas homossexuais. Quando se trata de Centros de Detenção Provisória e Penitenciárias, onde há muitas celas e diariamente banhos de sol e atividades laborais ou esportivas, é possível constituir celas exclusivas de homossexuais e, também, garantir o contato com os presos heterossexuais - isso traria maior segurança e também evitaria a segregação. No entanto, tal fato nem sempre é visto ou entendido como possível. Por exemplo: houve momento em que os pavilhões de determinadas unidades prisionais do Brasil possuíam celas específicas para os gays, travestis, transexuais e transgêneros (reivindicação antiga do movimento LGBT), no entanto, enquanto as celas com presos heterossexuais possuíam 2,5 vezes mais presos que a capacidade, as celas de homossexuais (recordando que no cenário prisional refere-se aos gays, "veados", "bibas") chegavam a ter um número de detentos que correspondia à metade dessa capacidade.

Ou seja, nesse aspecto o segmento GBT chegou a ter relativo "conforto", principalmente porque não dividia cela com o potencial agressor. No entanto, não demorou (a pedido da própria população carcerária) para que os gays, bissexuais, travestis, transexuais e transgêneros fossem redistribuídos. Assim, algumas celas do pavilhão "aceitaram" um detento homossexual (gay, "biba", "veado", "mona"), a fim de desativar cela exclusiva do público GBT - consequentemente, sobraria espaço para realocar outros detentos de celas que estavam mais cheias. 
Por outro lado, foi de encontro com aquilo que reza a legislação vigente, a saber: preservação da integridade física e mental.

\section{Considerações finais}

A heteronormatividade estabelece regras diferentes para o segmento de GBTs. Essas normas degradantes e discriminatórias impõem a estes indivíduos uma dupla exclusão: são os excluídos dos excluídos. Muito mais que a violência física, estão sujeitos a violências psicológicas e morais (Silva; Costa; Freitas, 2014). A vulnerabilidade e o risco decorrentes desta exclusão perversa não se findam após o cumprimento da pena e o ganho da liberdade, uma vez que retornando à sociedade estarão duplamente estigmatizados como: ex-presidiários, desajustados sexual e moralmente.

Se, por um lado, as travestis, transexuais e transgêneros conquistaram o direito de serem chamadas pelo nome social e não serem obrigadas a raspar o cabelo (desconsideradas as exceções), por outro, é preocupante que alguns ditames da Constituição Federal não estejam sendo observados: "ninguém será submetido à tortura nem a tratamento desumano ou degradante" (inciso III - artigo $5^{\circ}$ ). O inciso XLIX do mesmo artigo também traz: "é assegurado aos presos o respeito à integridade física e moral". No âmbito do sistema carcerário, predomina um desrespeito flagrante aos direitos humanos eà dignidade do segmento GBT encarcerado.

É de suma importância e urgência a proposição de políticas públicas para coibir o fenômeno da violência e preconceito contra as minorias dentro e fora das prisões. É extremamente necessário compreender a dinâmica e a lógica das instituições fechadas, o processo de "mortificação do eu" e o tolhimento do processo de produção de subjetividade. É neste sentido que Vicentin (2010) afirma que estamos próximos de uma resistência-sobrevivência, uma situação que se encontra no limite dos patamares de uma sociedade pautada no bem comum. Na luta contra a barbárie, "estabelecer um novo sistema de valores, de atitudes e de forma de vida é vital, e dessa capacidade resultará o êxito em salvaguardar a própria vida e a de outros" (Vicentin, 2011: 102).

Contudo, pode-se afirmar que o segmento carcerário de GBTs, no cotidiano da dinâmica prisional, está sendo submetido a relações de violência e capturado por rígidas hierarquias e regras heteronormativas. As manifestações sexuais e de gênero, distintas da heterossexual, são violentadas, exploradas e perseguidas. Sendo assim, nos espaços de poder, na convivência comum, a expressão das diferenças sexuais, aquelas que escapam da norma e do padrão, é limitada, 
cerceando ainda mais a promoção da cidadania e da reinserção social do presidiário.

Quanto à denominação dos sujeitos desta pesquisa, percebe-se na dinâmica da instituição que a diversidade sexual e de gênero não se reduz ao segmento homossexual. Concordamos com Zamboni (2017: 112), que propõe ir além, mesmo que provisoriamente, das categorias identitárias mobilizadas por agentes do Estado e por movimentos sociais "para interpelar esses sujeitos (como homossexuais, travestis e transexuais) e entender que outras categorias e sistemas classificatórios locais emergiam do cotidiano das prisões".

Quanto ao encarceramento deste social segmento em penitenciárias destinadas à população masculina, a face perversa é que a heteronormatividade os representa como seres "inferiores e desprezíveis", e isso justifica os atos de violência, crueldade, assédio moral e abuso sexual a que são submetidos. Por outro lado, ressalte-se que a política de alas ou celas específicas para essa população foi uma demanda do movimento de transexuais e transgêneros, consubstanciando uma atitude de defesa da integridade física, psíquica e moral.

Nesse sentido, Zamboni (2017: 113) nos alerta que, analisando a dinâmica das prisões onde a política de administração não obteve êxito, no aspecto de prevenção e mediação da violência, nota-se "que existem formas de segregação espacial que já operam com base em diferenças sexuais e de gênero - e que essas políticas públicas podem acabar por reforçar certas formas de discriminação". O autor anteriormente citado indica que:

Além disso, é preciso compreender que a convivência entre esses presos vistos pelo Estado como LGBT e o restante da população carcerária permite certas formas de agência fundamentais para esses sujeitos - seja para as suas condições materiais de existência (por meio das diversas formas de ativa, em especial a prostituição), ou seja, para a sua realização afetiva e sexual (por meio de relações com homens que não necessariamente se identificam como parte de uma população LGBT). (Zamboni, 2017: 114)

Por outro lado, Baptista-Silva, Hamann e Pizzinato postulam que o cárcere fomenta possibilidades únicas de conjugalidade, as quais só existem nesse lugar-tempo e são produzidas por redes de cuidado, gerando laços sociais, ou seja, vínculos coletivos. E, neste sentido, mesmo operando por estratégias de controle, disciplina e assujeitamento, é possível o fortalecimento de espaços institucionais capazes de funcionar como "um campo de dissenso político, tanto das 
relações (hiper)identitárias, como das condições de possibilidade de expressão e vivência de relações afetivo-sexuais" (2017: 384).

Em síntese, percebe-se, na dinâmica institucional e subjetiva, um movimento de resistência dos segmentos GBTs contra a violência, crueldade e tortura (física ou mental), bem como o direito de escolher aonde cumprir a pena, de acordo com sua orientação sexual e identidade de gênero. No caso de transexuais e transgêneros, especialmente, o direito ao próprio corpo, a realizar as transformações que desejar, a ter liberdade de vestimenta, pois a configuração identitária é uma metamorfose sistemática.

Enfim, cabe a reflexão de Nascimento (2018) ao afirmar que a narrativa das transformações da travestilidade nos permite pensar as performatividades de gênero enquanto um discurso de resistência. Nesse movimento, constroem-se histórias sobre si, tendo em vista atributos considerados pelos próprios sujeitos como femininos e, assim, objetivados nos corpos em mudança. Essa performance deve ser compreendida em sua dimensão ética e política, no enfrentamento coletivo, a qual faz parte de uma teia de discursos subjetivados ao longo da formação do transexual enquanto sujeito de sua existência, num contexto que banaliza os maus-tratos e a alienação. Numa subjetividade em constante transformação, a heteronormatividade dos cárceres é uma violência a ser combatida e superada.

\section{Referências}

ALMEIDA, Bruno Rotta; CHIES, Luiz Antônio Bogo. Editorial (Aproximações e disjunções penitenciárias desde o Cone Sul). Revista Sociedade em Debate (Universidade Católica de Pelotas), v. 22, n. 2, 2016, pp. 7-14.

BAPTISTA-SILVA, Gabriela; HAMANN, Cristiano; PIZZINATO, Adolfo. Casamento no Cárcere: Agenciamentos Identitários e Conjugais em uma galeria. Paidéia. v. 27, n. 1, 2017, pp. 376-385.

BRASIL. Constituição. Constituição da República Federativa do Brasil. Promulgada em 05 de outubro de 1988. Organização de Alexandre de Moraes. 41. ed. São Paulo, Atlas, 2015.

Conselho Nacional de Política Criminal e Penitenciária e Conselho Nacional de Combate à Discriminação. Resolução Conjunta $n^{\circ} 1$, de 15 de abril de 2014 . Estabelece parâmetros de acolhimento de LGBT em privação de liberdade no Brasil. Diário Oficial, Brasília, DF, 17 abr. 2014. (nº 74, Seção 1, p. 1).

. Ministério da Justiça (Departamento Penitenciário Nacional). Levantamento Nacional de Informações Penitenciárias INFOPEN - junho de 2016. DEPEN, junho 
de 2016. Disponível em: <http://depen.gov.br/DEPEN/noticias-1/noticias/infopen-levantamento-nacional-de-informacoes-penitenciarias-2016/relatorio_2016_22111. pdf $>$. Acesso em: 25 abr. 2019.

EUSTAQUIO JUNIOR, Cicero Pereira et al. Qualidade de vida de detentos (as) da "Primeira Ala LGBT do Brasil". Bagoas - Estudos Gays: Gêneros e Sexualidades. n.13, 2015, pp. 253-277.

FOUCAULT, Michel. Vigiar e punir: História da violência nas prisões. Petrópolis, Vozes, 1989.

GOFFMAN, Erving. Manicômios, prisões e conventos. São Paulo, Perspectivas, 1979. . A representação do eu na vida cotidiana. Petrópolis, Vozes, 2009.

KIEFER, Sandra. Homossexuais contam abusos que sofriam em prisões sem separação. O Estado de Minas, 25 nov. 2014. Disponível em: <http://www.em.com.br/app/ noticia/gerais/2014/11/25/interna_gerais,593189/uma-questaode-respeito.shtml>. Acesso em: 25 abr. 2019.

NASCIMENTO, Francisco Elionardo de Melo. A inscrição do feminino no corpo travesti: a trajetória das transformações da travestilidade de Renata. História e Cultura (Franca). v. 7, n. 1, 2018, pp. 221-237.

PINHEIRO, Luci Faria; GAMA, Taíza da Silva. As Origens do Sistema Penitenciário Brasileiro: uma análise sociológica da história das prisões do Estado do Rio de Janeiro. Revista Sociedade em Debate (Universidade Católica de Pelotas). v. 22, n. 2, 2016, pp. 157-190.

RIO DE JANEIRO. Secretaria Estadual da Administração Penitenciária. Resolução SEAP 558, de 29 de maio de 2015. Estabelece diretrizes e normativas para o tratamento da população LGBT no Sistema Penitenciário do Estado do Rio de Janeiro. Diário Oficial, Rio de Janeiro, 03 jun. 2015.

SÃO PAULO. Secretaria da Administração Penitenciária. Resolução SAP no 11, de 30 de janeiro de 2014. Dispõe sobre a atenção às travestis e transexuais no âmbito do sistema penitenciário. Diário Oficial, São Paulo, 31 jan. 2014.

SILVA, Diego Patrick; COSTA, Nicole Gonçalves; FREITAS, Rafaela Vasconcelos. Sistema Prisional, Identidade de Gênero e Travestilidades em Belo Horizonte. Anais do Encontro da ANDHEP - Políticas Públicas para a Segurança Pública e Direitos Humanos, 8. 2014. São Paulo, USP, 2014, pp. 2-15.

VICENTIN, Maria Cristina G. Os intratáveis: a patologização dos jovens em situação de vulnerabilidade. In: CRP-SP - Grupo Interinstitucional Queixa Escolar (Org.). Medicalização de crianças e adolescentes: conflitos silenciados pela redução de questões sociais a doenças de indivíduos. São Paulo, Casa do Psicólogo, 2010, pp. 41-55.

. Corpos em rebelião e o sofrimento-resistência: adolescente em conflito com a lei. Tempo Social (USP. Impresso), v. 23, 2011, pp. 97-113. 
ZAMBONI, Marcio. O barraco das monas na cadeia dos coisas: notas etnográficas sobre a diversidade sexual e de gênero no sistema penitenciário. Aracê - Direitos Humanos em Revista, v. 4, n. 5, 2017.

Recebido em 08/12/2017

Aprovado em 07/11/2018

\section{Como citar este artigo:}

CARVAlHO, Eder Aparecido de. PAULA, Alexandre da Silva de e KODATO, Sergio. Diversidade sexual e de gênero no sistema prisional: discriminação, preconceito e violência. Contemporânea - Revista de Sociologia da UFSCar, v. 9, n. 1, jan.- jun. 2019, pp. 253-273. 